ROCZNIKI PSYCHOLOGICZNE/ANNALS OF PSYCHOLOGY

2020, XXIII, 4, 367-374

DOI: https://doi.org/10.18290/rpsych2 $0234-4$

\title{
INTERDISCIPLINARY APPROACH TO HUMILITY: A REVIEW OF HANDBOOK OF HUMILITY: THEORY, RESEARCH, AND APPLICATIONS, EDITED BY WORTHINGTON ET AL.
}

\begin{abstract}
Empirical science terminology generally understands humility as a self-view grounded trait characterized mainly by accurate self-awareness and manifested respect for others. Related studies have been carried out for almost 20 years; however, it is still a quite new area in psychological research. Moreover, this seems to be an interesting area because of rising egocentric and narcissistic tendencies that are inconsistent with humble attitudes. Handbook of Humility: Theory, Research, and Applications, reviewed here, offers an adequate basis for understanding humility. It presents main aspects of interdisciplinary approach to humility-related issues like definitions, measurement, and its manifestations in different contexts. Readers may find there many questions and thesis broadening their perspectives, which is a good starting point to carry out own research.
\end{abstract}

Keywords: humility; intellectual humility; virtue; book review.

Through thousands of years, philosophers and religious leaders have focused on virtues that should drive human behavior in terms of their teachings. One such example is the virtue of humility promoted particularly in ancient Greek philosophy and Christian theology as moderation in action and intellectual deed (see Aquinas, 1485/1963; Aristotle, 347-330/2007). Although many authorities put their efforts into making this virtue widespread, however, scientific research does not seem to be consoling. A meta-analysis performed by Twenge et al. (2008)

Correspondence concerning this review can be sent to BARTOSZ WóJTOwicz, MA, Institute of Psychology, The John Paul II Catholic University of Lublin, Al. Racławickie 14, 20-950 Lublin, Poland; e-mail: bartosz.wojtowicz@kul.pl; ORCID: https://orcid.org/0000-0002-9390-6973. 
displays a rise in narcissism tendencies in the span of the last 27 years: TV shows focus predominantly on being famous (Uhls \& Greenfield, 2011), song lyrics present a very egocentric full of antisocial behaviors worldview (DeWall et al., 2011), the same can be said about books - that is, currently they present more often individualistic attitudes towards life than in the past (Twenge et al., 2012). Moreover, in terms of information seeking, scientists have observed a default tendency to value one's own beliefs more than others (for a meta-analysis, see Hart et al., 2009).

However, there is a light at the end of the tunnel: Handbook of Humility: Theory, Research, and Applications, which potentially answers many questions related to humility that in empirical science is generally known as a self-view grounded trait (Ou et al., 2014). Humility consists of four components: accurate self-awareness, appreciation of others, openness to feedback, and transcendence perspective (Nielsen \& Marrone, 2018). Specific studies have showed that humble people are aware of both their strengths and weaknesses (e.g., Tangney, 2000). Moreover, they are characterized by an openness to others contributions and views (e.g., Owens \& Hekman, 2012). They also don't tend to over- or under-represent the self (e.g., Morris et al., 2005). In addition, it is worth noticing that humility can manifest in some specific contexts. Nowadays, there are such subdomains known as intellectual humility (Gregg et al., 2017; Krumrei-Mancuso \& Rouse, 2016; Leary et al., 2017), cultural humility (Danso, 2018), domain related to political issues (Krumrei-Mancuso \& Newman, 2020; Stanley et al., 2020), and to spiritual/religion context (Hodge et al., 2019; Hook et al., 2017). In each one, the main aspects of humble attitudes are accurate self-awareness, openness, and respect for others.

This Handbook published in November 2017 (ISBN 978-1-138-96001-5, 366 pages) is edited by Everett L. Worthington (Virginia Commonwealth University), Don E. Davis (Georgia State University), and Joshua N. Hook (University of North Texas). It is a new book item from Routledge/Taylor \& Francis Group's series of handbooks that provides an interdisciplinary analysis of humility. The authors, proponents of the positive psychology trend that focuses on positive mood states and virtues (Seligman \& Csikszentmihalyi, 2000), set a goal to give a basis for learning and testing humility. What is more, they aim at answering questions regarding humility's definitions, the existence of its subdomains, results of psychological research, and their implications. The goal set by them does not seem to be approachable easily - to achieve it, one must use a combination of different scientific disciplines; the same applies to analyzing their results. Philosophy, ethics, psychology, and political sciences have different subjects of 
study, methods and yield different research findings. Worth noticing is also the supposition that humility is a positive virtue, which may ensue in a bias, highlighting the positive side of this construct. The following section describes every one of the three parts constituting the handbook in two paragraphs. First, the review starts with a brief description of chapters and a short synopsis, followed by a cumulative assessment of the whole text.

In the first part, titled "Theory, definitions, and measurement," the reader will find eight chapters devoted to defining humility, its subdomains, and measurement methods. The first three analyses of the virtue of humility approach it from different academic standpoints. Jeffrie G. Murphy in "Humility as a moral virtue" proposes some reflections basing on moral processes and decisions. Referring to Dickens and Shakespeare's literature and philosophies, he argues that humility is a "cluster virtue" which needs humanities to define its nature. Then, Robert C. Robert and W. Scott Cleveland, in their chapter titled "Humility from a philosophical point of view," present a critical overview of various definitions of humility. Interestingly, they undermine a common belief of a simple humilitypride continuum in favor of the thesis that the nature of humility is much more intricate. Steven L. Porter et al. discover in their "Religious perspectives on humility" that, conversely to the fact that the biggest five religions comprehend humility in different ways, they put it on the top of their hierarchy of virtue. Authors also enquire whether it is possible to understand humility without any religious context. The next four chapters describe the particular subdomains of humility. "Intellectual humility," written by Ian M. Church and Justin L. Barret, depicts its new intellectual definitions based on the concept of positive epistemic status, critically referring to past classifications. Everett L. Worthington, in his "Political humility," describes another subfield for research. He argues that general humility has its consequences and results in a political context that make a separate construct. He also presents a brief guide on how to be politically humble and its application. David K. Mosher's academic team describes cultural humility. Their article with the same title shows intra- and interpersonal indicators of humility in a cultural context. They provide theoretical and empirical literature as confirmation for their thesis. Don E. Davis et al. argue in their "Relational humility" that, while one scores high in self-report humility's scale it might be caused by bragging. Then, they propose next subdomain-it refers to precepted humility in others. They also indicate on potential drawbacks of being humble. The last chapter in this part, called "A few good measures," presents psychometric measures of humility. Interestingly enough, it is inspired by Rob Reiner's film A Few Good Men (1992) and based on the story of the main 
character, Colonel Nathan R. Jessup. The authors, Peter C. Hill and colleagues, highlight possibilities and limitations of measurements of humility and its subdomains.

Summing up the first part presents humility from different scientific approaches - ethical, philosophical, religious, political, and psychological. It is an interdisciplinary consideration of what humility is. What is important, rather than a ready and "solely true" answer, is that the reader will find a cross-section of various meanings. Moreover, the virtue of humility is divided into subdomains. It raises the question of whether there are many different types of humility, or maybe the general humility is manifested in different contexts? Certainly, scientists still need to put much effort into defining this phenomenon clearly.

The second part of the book is called "Predictors, correlates, and sequelae of humility" and contains five chapters. They all present brief literature reviews. This part starts with "Personality predictors and correlates of humility," where Joseph Leman operationalizes humility as an Honesty-Humility scale's score. He proposes humility to be "the sixth big trait" and shows its negative correlations. Daryl R. Van Tongeren and David G. Myers in "A social psychological perspective on humility" show in turn how relational humility with regard to the perception of one's self-image; they analyze its role in social processes and give a few ways to reduce biases like overconfidence or being better than average. Advice on how to behave humbly is given here, however, drawbacks are pointed out as well. The next article, titled "Relational predictors and correlates of humility," written by Jeffrey D. Green et al., depicts the interdependence theory (Kelley \& Thibaut, 1978) and the investment model of commitment (Rusbult, 1980) as a framework for relational humility research. Moving forward, Loren L. Toussaint and Jon R. Webb in "The humble mind and body" present a theoretical model of relations between humility and mental health. They also show that abilities related to humility (e.g., self-regulation) mediate that connection. In the least article, called "Spiritual and religious predictors, correlates and sequelae of humility," a variety of humility's definitions are reduced to a state of ego disinvolvement. Authors, Mark M. Leach and Adebayo Ajibade, present a brief literature review of links between humility, religion, and spirituality.

To sum up the second part of the Handbook, it is a natural continuation of previous chapters: once definitions were presented, there is a possibility to carry out basic research testing those theoretical considerations. This part focuses on empirical research describing humility in the context of personality, social and dyadic relationships, religiosity, spirituality, and mental health issues. Readers might get to know that humility is a significant correlator and predictor 
of already documented variables. Moreover, they can discern how different definitions and measures are being used. Having established such a basis for discussion, we can analyze more the practical part itself.

The third part, titled "Applications of humility to relationships and treatment," concludes the Handbook. Firstly, Bryan J. Dik et al. in "Humility in career development" critically analyze the influence of being humble on the success of one's career path. They find both positive and negative outcomes. "Humility in romantic relationships" written by Rachel C. Garthe et al. depicts humility's beneficent role in adaptive processes within dyads. Moving forward, C. Nathan DeWall, in "Fostering intellectual humility in public discourse and university education," describes how intellectual humility positively affects academic life. Moreover, he adds examples of personal cases related to this hypothesis. In "Organizational humility and the better functioning business nonprofit and religious organizations," readers can discover the potential benefits and harmful effects of introducing the humble attitude in a business environment. Angela S. Wallace, Chia-Yen (Chad) Chiu, and Bradley P. Owens base on a history of leadership scandals through the past 50 years that appeared because of lack of humility. The two next chapters show possibilities of experimental modification of humility. Peter M. Ruberton, Elliot Kruse, and Sonja Lyubomirsky in "Boosting state humility via gratitude, self-affirmation and awe" present three experimental manipulations that display an increased indicator of humility. On the other hand, Caroline R. Lavelock et al. in "Humility intervention research" point at another method related to behavioral tasks like special therapies. This text gives readers a smooth transition into the last four chapters embedded in the clinical domain. "Humility and psychotherapist effectiveness," written by Edward B. Davis and Andrew D. Cuthbert, is focused on humility's role in enhancing the therapist-patient relationship. Then, Steven J. Sandage and his colleges in "Humility in psychotherapy" provide the reader with a discussion about acting humble in therapeutic dyads. Interestingly, humility is understood here as a virtue and a holistic attitude rather than having a special ability or a trait. Subsequently, Joanna M. Drinane et al. in "Microaggressions and cultural humility in psychotherapy" argue how this subdomain of general humility work against assumptions and biases. Finally, "The clinical application of humility to moral injury" written by Brandon J. Griffin et al. show how humility can influence the treatment of moral injury in the military context.

The following chapters of the third part may be perceived as an explication of the second part. The presented research describes not only humility but also concerns its role in psychologists' practice. The reader can see how humility acts 
in psychotherapy, business, the university community, and romantic relationships. What is important, the ways to develop humility are also shown. On the other hand, the literature confirming the presented hypothesis is not comprehensive at all, which is why some conclusions included in this part have speculative character.

Having read this handbook, one may conclude that its evaluations might be polarized. The readers who expected a clear definition of humility and simple answers will surely be disappointed. The chapters present attempts to find real meanings rather than giving quick responses. Moreover, the book shows that even though humility is known to be a virtue, it may have drawbacks. It seems to be clear, as the authors claim, that the research focused on humility has started, and still much time and effort are required to establish a mature paradigm and theories. On the other hand, scientists looking for a starting point to create theories, construct accurate measurements, and discover real answers have a book item that presents them with the place to start. Humility is displayed here as a complex concept that needs a variety of references to be described well. Thus, representatives of different academic disciplines like ethics, philosophy, and psychology have their own contributions. However, observant readers may point to the methodology of cited research - most of them use only correlational models. Even though results come from experimental methods, they are ambiguous and do not show any clear causal conclusions. Thus, this part of science is still undiscovered, and those inquisitive readers ought to follow current literature or carry out their own studies. Summing up, the Handbook reviewed here achieves the goal to lay a foundation for further scientific exploration of humility.

\section{REFERENCES}

Aquinas, T. (1963). Suma Teologiczna (W. Bednarski, Trans.; Vol. 12). Veritas.

Aristotle. (2007). Etyka Nikomachejska (D. Gromska, Trans.; Vol. 5). PWN.

Danso, R. (2018). Cultural competence and cultural humility: A critical reflection on key cultural diversity concepts. Journal of Social Work, 18(4), 410-430. https://doi.org/10.1177/14680 17316654341

DeWall, C. N., Pond, R. S., Campbell, W. K., \& Twenge, J. M. (2011). Tuning in to psychological change: Linguistic markers of psychological traits and emotions over time in popular U.S. song lyrics. Psychology of Aesthetics, Creativity, and the Arts, 5(3), 200-207. https://doi.org/10.1037/a0023195

Gregg, A. P., Mahadevan, N., \& Sedikides, C. (2017). Intellectual arrogance and intellectual humility: Correlational evidence for an evolutionary-embodied-epistemological account. The Journal of Positive Psychology, 12(1), 59-73. https://doi.org/10.1080/17439760.2016.11 67942 
Hart, W., Albarracín, D., Eagly, A. H., Brechan, I., Lindberg, M. J., \& Merrill, L. (2009). Feeling validated versus being correct: A meta-analysis of selective exposure to information. Psychological Bulletin, 135(4), 555-588. https://doi.org/10.1037/a0015701

Hodge, A. S., Melian, K., Gazaway, S., Hook, J. N., Zhang, H., Farrell, J. E., Mosher, D. K., Captari, L. E., \& Coomes, S. P. (2019). Exploring religious intellectual humility and spiritual humility. Journal of Psychology and Christianity, 38(1), 22-34.

Hook, J. N., Farrell, J. E., Johnson, K. A., Van Tongeren, D. R., Davis, D. E., \& Aten, J. D. (2017). Intellectual humility and religious tolerance. The Journal of Positive Psychology, 12(1), 29-35. https://doi.org/10.1080/17439760.2016.1167937

Krumrei-Mancuso, E. J., \& Newman, B. (2020). Intellectual humility in the sociopolitical domain. Self and Identity, 19(8), 989-1016. https://doi.org/10.1080/15298868.2020.1714711

Krumrei-Mancuso, E. J., \& Rouse, S. V. (2016). The development and validation of the Comprehensive Intellectual Humility Scale. Journal of Personality Assessment, 98(2), 209221. https://doi.org/10.1080/00223891.2015.1068174

Leary, M. R., Diebels, K. J., Davisson, E. K., Jongman-Sereno, K. P., Isherwood, J. C., Raimi, K. T., Deffler, S. A., \& Hoyle, R. H. (2017). Cognitive and interpersonal features of intellectual humility. Personality and Social Psychology Bulletin, 43(6), 793-813. https://doi.org/10.1177/0146167217697695

Morris, J. A., Brotheridge, C. M., \& Urbanski, J. C. (2005). Bringing humility to leadership: Antecedents and consequences of leader humility. Human Relations, 58(10), 1323-1350. https://doi.org/10.1177/0018726705059929

Nielsen, R., \& Marrone, J. A. (2018). Humility: Our current understanding of the construct and its role in organizations: Humility. International Journal of Management Reviews, 20(4), 805824. https://doi.org/10.1111/ijmr.12160

Ou, A. Y., Tsui, A. S., Kinicki, A. J., Waldman, D. A., Xiao, Z., \& Song, L. J. (2014). Humble chief executive officers' connections to top management team integration and middle managers' responses. Administrative Science Quarterly, 59(1), 34-72. https://doi.org/10.1177/0001839 213520131

Owens, B. P., \& Hekman, D. R. (2012). Modeling how to grow: An inductive examination of humble leader behaviors, contingencies, and outcomes. Academy of Management Journal, 55(4), 787-818. https://doi.org/10.5465/amj.2010.0441

Rusbult, C. E. (1980). Commitment and satisfaction in romantic associations: A test of the investment model. Journal of Experimental Social Psychology, 16(2), 172-186. https://doi.org/10. 1016/0022-1031(80)90007-4

Seligman, M. E. P., \& Csikszentmihalyi, M. (2000). Positive psychology: An introduction. American Psychologist, 55(1), 5-14. https://doi.org/10.1037/0003-066X.55.1.5

Stanley, M. L., Sinclair, A. H., \& Seli, P. (2020). Intellectual humility and perceptions of political opponents. Journal of Personality, 88(6), 1196-1216. https://doi.org/10.1111/jopy.12566

Tangney, J. P. (2000). Humility: Theoretical perspectives, empirical findings and directions for future research. Journal of Social and Clinical Psychology, 19(1), 70-82. https://doi.org/10. $1521 /$ jscp.2000.19.1.70

Twenge, J. M., Campbell, W. K., \& Gentile, B. (2012). Increases in individualistic words and phrases in American books, 1960-2008. PLOS ONE, 7(7), e40181. https://doi.org/10.1371/ journal.pone.0040181 
Twenge, J. M., Konrath, S., Foster, J. D., Keith Campbell, W., \& Bushman, B. J. (2008). Egos inflating over time: A cross-temporal meta-analysis of the Narcissistic Personality Inventory. Journal of Personality, 76(4), 875-902. https://doi.org/10.1111/j.1467-6494.2008.00507.x

Uhls, Y. T., \& Greenfield, P. M. (2011). The rise of fame: A historical content analysis. Cyberpsychology: Journal of Psychosocial Research on Cyberspace, 5(1). https://cyberpsychology. eu/article/view/4243 